(5) Blatt (Roumania).- The problem of the partial and total transplantation of eyes. (Das Problem der partiellen und totalen Augentransplantation.) Arch.f. Ophthal., Vol. CXIV., 1924.

(5) Blatt was induced to repeat the experiments made by Koppányi (vide Brit. Jl. of Ophthal., Vol. VIII, p. 486, 1924), who claimed to have transplanted eyeballs in toto with great success from a functional as well as an anatomical point of view, and in recording his results he first gives a wide survey of the whole question of regeneration and transplantation in the lower animals and in man.

The author employed 400 freshwater fishes, eighty rabbits, and forty fowls, and out of these the transplanted eyes were retained, with slight changes in the refractive media, in 26 fishes and only two rabbits. In the case of the fishes observations to test the reacquirement of vision in the transplanted eyes were made on their behaviour in the presence of a bright light and on feeding, their attitude in swimming and their change in colour and it was definitely found that they behaved in exactly the same way as blind fishes. The same negative result as to vision was obtained in the two rabbits in which the eyes were retained. In the fowls the transplanted eye was in every case lost.

Heteroplastic transplantation of an eyeball, the author adds, has been tried in man but never with lasting success and on theoretical grounds as well as on account of the technical difficulties involved it is very questionable whether the homoioplastic method would be attended with better result.

Thos. SNowball.

\title{
BOOK NOTICES
}

Disc-shaped Degeneration of the Central Parts of the Retina. (Die Scheibenformige Entartung der Netzhautmitte.) By Paul Junius and Hermann Kuhnt. Berlin: S. Karger, 1926.

This book is a very remarkable example of perfect production. The paper, printing, and the excellence of the many coloured illustrations, are extraordinarily good. We gather from a note in the introduction that the cost of production was partially defrayed by a "German Science Necessities Fund." This fund apparently is prepared to help in the production of scientific work which would be impossible on ordinary commercial lines.

In essence the book consists of a full description of ten cases of this rare affection. There are also references to cases from the literature. Under the description "Disc-Shaped Macular Disease" 
the authors understand those cases of macular degeneration accompanied by haemorrhage, with or without exudate, which have been described in this country by Rayner Batten as "Peculiar symmetrical swellings in the macular region," and by Lawford as "Subretinal new growth." There is also a case described by Hutchinson in 1876 as "Symmetrical central choroido-retinal disease," and there are many other similar observations. The authors come to the conclusion that the disease originates in some affection of the capillary vessels of the central retinal area, permitting blood exudation and causing degeneration of the tissues concerned. There is frequently an accompanying degeneration of the chorio-capillaris. The characteristic shape of the macular affection is to be explained by the peculiarity of the vascular distribution of this region, and in this connection it is of interest to recall the remarks of Percival Hay on "The Nutritive Supply of the Macular Region" given in the Transactions of the Ophthalmological Society of the United Kingdom of 1921.

This book will repay careful study by all who are interested in this fascinating but obscure field of retinal disease.

Colour Blindness. By Julia Bell, M.A., M.R.C.S., L.R.C.P. With plates XXVII-XLI and frontispiece portrait of John Dalton; pedigrees 367-602. Eugenics Laboratory Memoirs, XXIII. The Treasury of Human Inheritance, edited by Karl Pearson, F.R.S., Vol. II Anomalies and Diseases of the Eye. Nettleship Memorial Volume, Part II. Cambridge University Press, 1926. Price 45 shillings net.

The chief value of this work consists in the collection of pedigrees of colour blindness, with as exhaustive notes as it has been possible to obtain of the individual cases. As Miss Bell herself says (p. 196) : "with regard to the pedigrees themselves the material is such as to make the statistician thoroughly unhappy, for we know perfectly that a large proportion of those individuals entered as normal have not been scientifically tested, and we know also that many of the cases amongst the earlier published records have been tested by means of wools alone which may be entirely misleading." None the less, the work was well worth doing and has been don excellently. It will be long before more accurate records can be collected and collated, but it is to be hoped that attention in the immediate future will be directed to the thorough scientific investigation of all the members of a few carefully selected pedigrees. It has been impossible in the present collection to distinguish the types of partial colour blindness, but the differences in protanopic and deuteranopic cases are so pronounced that it is not safe to conclude that they follow the same laws of inheritance or are mixed 
in the same pedigrees. The impossibility of distinguishing the milder forms (protanomalous and deuteranomalous)-not to speak of other anomalies, such as a shift of the sensation curves-by crude methods of examination introduces the probability of serious errors in the pedigrees and the results which can be deduced from. them.

Miss Bell has written quite an extensive thesis on colour blindness as an introduction to the pedigrees. This is quite admirable, so far as it goes, especially in the cautiousness of her treatment of theories and the deductions therefrom. The introduction is divided into three parts : (1) Colour Vision and its Anomalies; (2) Total Colour Blindness; (3) Congenital Colour Blindness. Of these that on total colour blindness is by far the best, and could scarcely be improved in the space allotted to it.

The first part commences with an historical account going back to Galen and Hippocrates. Interesting as it is, we think that it, and some other of the sections less pertinent to the main object of the thesis might, in the interests of economy, have been published elsewhere; for we fear that the cost of the production may limit its dissemination. In fact, we think that the whole of this part, dealing with normal colour vision, the solar spectrum, the structure of the human retina, on the association of retinal structure and function in man and in animals, the neuro-epithelial layer of the retina, and colour vision in animals might have been treated more cursorily, for these subjects cannot be adequately dealt with in the space allotted, have been discussed more fully in readily accessible works, and should be familiar to all who are sufficiently interested in the subject to turn their attention to the inheritance of anomalies.

No attempt is made in the third part to discuss so exhaustively the ordinary forms of colour blindness and the multitudinous theories on the subject. Here, and quite rightly in our opinion, stress is laid upon the frequency of colour blindness, its incidence in women, and its inheritance. The heading "Congenital Colour Blindness," though sanctified by usage, is not very happy at any rate without the qualifying adjective "partial."

All these criticisms are, however, of quite secondary importance as compared with the value of the work as a whole. The author expresses her indebtedness to $\mathrm{Mr}$. C. H. Usher, who with his usual modesty well-nigh effaces himself; but a mere glance at the pedigrees proves that his aid and the pioneer work and inspiration of Mr. E. Nettleship to whom the work is dedicated, are responsible for the best and most complete pedigrees in the collection.

Sumptuous seems to be the only word which is adequate to describe the form and printing of the book. 